\title{
FAKTOR - FAKTOR YANG MEMPENGARUHI KINERJA UMKM BIDANG KULINER PADA MASA PANDEMI COVID - 19
}

\begin{abstract}
Keren Eunike dan Louis Utama
Program Studi Manajemen Fakultas Ekonomi dan Bisnis, Universitas Tarumanagara, Jakarta Email : keren.115170146@stu.untar.ac.id louisu@fe.untar.ac.id

Abstract: The purpose of this study is to find out whether Entrepreneurship Skills, Market Orientation, Sales Orientation, and Entrepreneurship Competence have an influence on the performance of SMEs in the culinary field. The population in this study is SMEs in the culinary sector. The sample used in this study were 50 respondens who owned MSMEs in the culinary field in Tanjung Duren, West Jakarta. The sampling technique used is non-probability sampling with purposive sampling method. Data collection was carried out using a Likert scale questionnaire. Overall the results of this study are that Entrepreneurship Skills have an influence on the performance of SMEs in the culinary field in Tanjung Duren, West Jakarta during the Covid-19 pandemic, Market Orientation has no effect on the performance of SMEs in the culinary field in Tanjung Duren, West Jakarta during the Covid-19 pandemic. 19, Sales Orientation has an influence on the performance of SMEs in the culinary field in Tanjung Duren, West Jakarta during the Covid-19 pandemic, Entrepreneurship Competence has an influence on the performance of SMEs in the culinary field in Tanjung Duren, West Jakarta during the Covid-19 pandemic.
\end{abstract}

Keywords : Entrepreneurial Skill, Market Orientation, Sales Orientation, Entrepreneurs Competency, Business Performance.

Abstrak: Tujuan penelitian ini adalah untuk mengetahui apakah Keterampilan Kewirausahaan, Orientasi Pasar, Orientasi Penjualan, dan Kompetensi Kewirausahaan memiliki pegaruh terhadap Kinerja UMKM bidang kuliner. Populasi dalam penelitian ini adalah UMKM bidang kuliner. Sampel yang digunakan pada penelitian ini yaitu 50 responden pemilik UMKM bidang kuliner di Tanjung Duren, Jakarta Barat. Teknik pengambilan sampel yang digunakan yaitu non probability sampling dengan metode pengambilan sampel purposive sampling. Pengumpulan data yang dilakukan dengan menggunakan kuesioner berskala Likert. Secara keseluruhan hasil dari penelitian ini yaitu Keterampilan Kewirausahaan memiliki pengaruh terhadap Kinerja UMKM bidang kuliner di Tanjung Duren, Jakarta Barat pada masa pandemi Covid-19, Orientasi Pasar tidak berpengaruh pengaruh terhadap Kinerja UMKM bidang kuliner di Tanjung Duren, Jakarta Barat pada masa pandemi Covid-19, Orientasi Penjualan memiliki pengaruh pengaruh terhadap Kinerja UMKM bidang kuliner di Tanjung Duren, Jakarta Barat pada masa pandemi Covid-19, Kompetensi Kewirausahaan memiliki pengaruh terhadap Kinerja UMKM bidang kuliner di Tanjung Duren, Jakarta Barat pada masa pandemi Covid-19. 
Kata Kunci : Keterampilan Kewirausahaan, Orientasi Pasar, Orientasi Penjualan, Kompetensi Kewirausahaan, Kinerja Usaha

\section{LATAR BELAKANG}

Pada tanggal 2 maret 2020 kasus positif covid - 19 ini pertama kali terdeteksi di Indonesia. Perlahan pandemi ini mempengaruhi dan menyebabkan kekacuan diberbagai sektor seperti sektor ekonomi, pariwisata khususnya dibidang kuliner. Tidak sedikit sebuah usaha yang sebelumnya ramai dikunjungi menjadi sepi karena pandemi covid - 19 ini. Banyak pemilik restoran yang terpaksa menuntup usahanya karena mengalami kebangkrutan. Bisnis kuliner mengalami penurunan pendapatan harian mencapai 37\%. Pandemi Covid-19 menyebabkan penurunan jumlah orderan sebesar $20 \%$ dari jumlah orderan biasanya (Burhan, 2020). Maka dari itu, para pemilik UMKM bidang kuliner perlu menyusun atau membuat strategi untuk memasuki era new normal agar bisnisnya tetap bisa berjalan. Peran penting orientasi kewirausahaan juga penting dalam bertahan melalui masa-masa gejolak ekonomi yang parah disebabkan oleh krisis ekonomi (Utama, 2017). Seorang pemilik UMKM bidang kuliner juga harus dapat mengambil resiko atas situasi yang tidak stabil ini salah satunya dengan menciptakan sesuatu yang berbeda dari para pesaing. Seorang wirausaha perlu menerapkan keterampilan kewirausahaan, orientasi pasar maupun orientasi penjualan agar sebuah usaha memiliki keunggulan kompetitif dan dapat mendorong kinerja usahanya (Rizan. \& Utama, 2020).

Seorang pemilik UMKM perlu meningkatkan keterampilan kewirausahaan karena menjadi seseorang yang terampil dibutuhkan ilmu dan latihan. Keberhasilan dalam berbisnis memerlukan lebih dari sekedar kerja keras, setiap pemilik usaha perlu menguasai keterampilan dasar dalam berwirausaha. Keterampilan kewirausahaan merujuk pada kegiatan atau pengetahuan yang dapat mengembangkan dan mengoperasikan perusahaan dengan sukses (Linan \& Chen, 2009). Kurangnya keterampilan kewirausahaan dapat menyebabkan seseorang sulit untuk memfasilitasi usahanya. Maka, keterampilan kewirausahaan adalah salah satu faktor penting dalam keberhasilan UMKM yang meliputi motivasi dan kemampuan dalam mengumpulkan sumber daya yang secara langsung akan meningkatkan kinerja usaha terutama pada masa pandemic Covid-19 ini (Muslimu \& Alhassan, 2020).

Setelah menguasai keterampilan kewirausahaan, seorang pemilik UMKM juga harus memperhatikan orientasi pasar. Orientasi pasar ini merupakan orientasi perusahaan yang berhubungan dengan promosi dan dukungan dalam pengumpulan dan menentukan peluang pasar untuk memenuhi kebutuhan pelanggan yang dapat meningkatkan kinerja sebuah usaha (Kohli \& Jawarski, 1990). Jika pemilik restoran tidak memperhatikan orientasi pasar, maka akan sulit dalam memfasilitasi perusahaan untuk memaksimalkan kinerjanya karena kurang memahami dan mengetahui keinginan pelanggan, dan strategi dalam menghadapi pesaing (Morgan et al, 2009).

Setelah itu, pemilik UMKM harus memperhatikan tentang orientasi pejualan. Orientasi penjualan mengacu pada wirausaha yang terlibat dalam kegiatan penjualan yang membutuhkan "mendapatkan suatu penjualan" dari setiap pelanggan (Jaramillo et al, 2007). Pemilik restoran yang kurang menguasai orientasi penjualan akan kurang berorientasi pada kepuasan konsumen, 
kurang memperhatikan layanan atau produk mereka dan kurangnya penjualan (Boles et al, 2001).

Setelah seorang pemilik UMKM menguasai keterampilan kewirausahaan, orientasi pasar dan orientasi penjualan, ia juga perlu memperhatikan kompetensi kewirausahaan agar memiliki jiwa pesaing. Kompetensi kewirausahaan ini berkaitan dengan pengetahuan, keterampilan dan kemampuan pemilik restoran dalam pengembangan sumber daya kompetensi kewirausahaan berhubungan dengan sumber daya tak berwujud dan berharga yang dapat berkontribusi pada keunggulan kompetitif perusahaan dalam berkinerja lebih maksimal (Tehseen \& Ramayah, 2015).

\section{KAJIAN TEORI}

Resource-Based View Theory (RBV) menganalisa serta menafsirkan sumber daya organisasi untuk memahami bagaimana sebuah organisasi mencapai keunggulan kompetitif yang berkelanjutan. RBV mengambil perspektif khusus perusahaan tentang mengapa organisasi berhasil atau gagal di pasar (Dicksen, 1996) dan berfokus pada atribut perusahaan yang sulit untuk ditiru sebagai sumber kinerja dan keunggulan kompetitif (Barney, 1986). Dasar teori ini adalah asumsi bahwa organisasi dapat memperoleh keunggulan kompetitif ketika dapat mengeksploitasi sumber daya heterogen yang melekat dalam organisasi yang berharga, langka, tak ada bandingannya dan tidak dapat diganti (Priem \& Butler, 2001)

Keterampilan Kewirausahaan. Keterampilan dan keyakinan kewirausahaan dibutuhkan oleh pemilik perusahaan dalam mengembangkan dan menjalankan perusahaan (Campbell et al, 2012). Penelitian sebelumnya mengatakan bahwa seorang wirausahawan memerlukan berbagai keterampilan untuk mengembangkan kompetensi yang terdapat pada diri seseorang untuk mengelola perusahaan (Phelan \& Sharpley, 2012).

Orientasi Pasar. Orientasi pasar diartikan sebagai orientasi perusahaan terhadap promosi dan dukungan untuk pengumpulan, penyebaran dan responsivitas terhadap pasar untuk memenuhi kebutuhan pelanggan yang dapat menjamin kinerja perusahaan (Kohli \& Jawarski, 1990). Orientasi pasar mencerminkan pembelajaran adaptif yang memungkinkan perusahaan untuk mengidentifikasi dan menanggapi perubahan lingkungan mereka melalui asumsi tentang konsumen dan persaingan (Atuahene-Gima \& Ko, 2001).

Orientasi Penjualan. Orientasi penjualan diartikan sebagai suatu kegiatan penjualan sebanyak-banyaknya dimana memprioritaskan kebutuhan pelanggan, mempresentasikan layanan dan produk mereka (Boles et al , 2001). Orientasi penjualan berfokus pada pengusaha yang terlibat dalam aktivitas penjualan yang membutuhkan penjualan sebanyak mungkin dari setiap pelanggan (Jaramillo, Ladik, Marshall, \& Mulki, 2007)

Kompetensi Kewirausahaan. Kompetensi kewirausahaan diartikan sebagai karakteristik individu yang meliputi sikap dan perilaku yang memungkinkan wirausahawan mencapai keberhasilan usahanya (Endi et al, 2013). Kompetensi kewirausahaan ini mencakup 
pengetahuan, keterampilan, dan kemampuan yang berharga yang dapat membantu perusahaan mencapai keunggulan kompetitif (Barney J., 1991).

Kinerja Usaha. Kinerja sebuah organisasi didefinisikan sebagai nilai ekonomi yang diperoleh dalam aktivitasnya atau volume penjualan yang dihasilkan dari strategi yang diikuti (Rumelt et al, 1994). Kinerja bisnis didefinisikan sebagai pencapaian tujuan organisasi terkait pertumbuhan penjualan, profitabilitas, dan pangsa pasar (Narver \& Slater, 1990).

\section{Pengaruh Keterampilan Kewirausahaan terhadap Kinerja Usaha}

Kapabilitas seorang wirausahawan tentang pengetahuan keterampilan dan kapabilitas lainnya dapat memfasilitasi kinerja perusahaan (Grant, 1991). Selain itu, keterampilan kewirausahaan juga berkaitan dengan karakteristik demografis, psikologis dan pengetahuan yang berpengaruh pada kinerja usaha (Gerli et al, 2011). Keterampilan dan keyakinan kewirausahaan sangat penting bagi perusahaan (Campbell et al, 2012).

\section{Pengaruh Orientasi Pasar terhadap Kinerja Usaha}

Pemahaman akan orientasi pasar yang baik dari sebuah perusahaan membuat perusahaan tersebut mampu menciptakan strategi pemasaran yang baik juga. Penerapan strategi pemasaran yang baik akan berdampak pada meningkatnya kinerja perusahaan. Kinerja perusahaan akan semakin baik seiring dengan semakin tepat dan baik nya strategi pemasaran yang berorientasi terhadap pasar yang diterapkannya. Dengan strategi yang sangat baik, perusahaan akan dapat menyasar pasar sasaran dengan sangat efektif dan efisien. Hal ini menunjukkan bahwa orientasi perusahaan pada pasar akan memberikan kontribusi yang signifikan pada peningkatan kinerja perusahaan. Orientasi pasar juga dikatakan merupakan budaya perusahaan yang bisa membawa pada meningkatnya kinerja (Kohli \& Jawarski, 1990).

\section{Pengaruh Orientasi Penjualan terhadap Kinerja Usaha}

Seorang wirausaha yang memiliki orientasi penjualan bertanggung jawab dalam mengimplementasikan strategi pelayanan perusahaan (Wetzels \& Lemmink, 2000). Seperti yang dikemukakan oleh RBV, perilaku berorientasi pada penjualan dianggap sebagai kemampuan perusahaan yang tidak dapat ditiru, yang kemudian dapat menghasilkan kinerja yang luar biasa dari perusahaan tersebut (Barney J., 1991). Orientasi penjualan juga dikatakan sebagai prediktor penting dari kinerja perusahaan di tingkat individu (Jaramillo et al, 2007).

\section{Pengaruh Kompetensi Kewirausahaan terhadap Kinerja Usaha}

Pada sebuah UMKM, kompetensi seorang wirausaha akan sangat mempengaruhi kinerja bisnisnya. Wirausaha beserta kompetensinya merupakan sumber daya penting dan berharga bagi perusahaan (Mitchelmore \& Rowley, 2010). Sumber daya perusahaan adalah hal yang berharga, langka, sulit ditiru, dan tak tergantikan, yang dapat menjadi keunggulan kompetitif bagi sebuah perusahaan. Kompetensi merupakan seperangkat faktor- faktor keberhasilan yang berkontribusi untuk mencapai kinerja tinggi dan hasil nyata (Wu, 2009). 
Model Penelitian dalam penelitian ini seperti yang digambarkan dibawah ini:

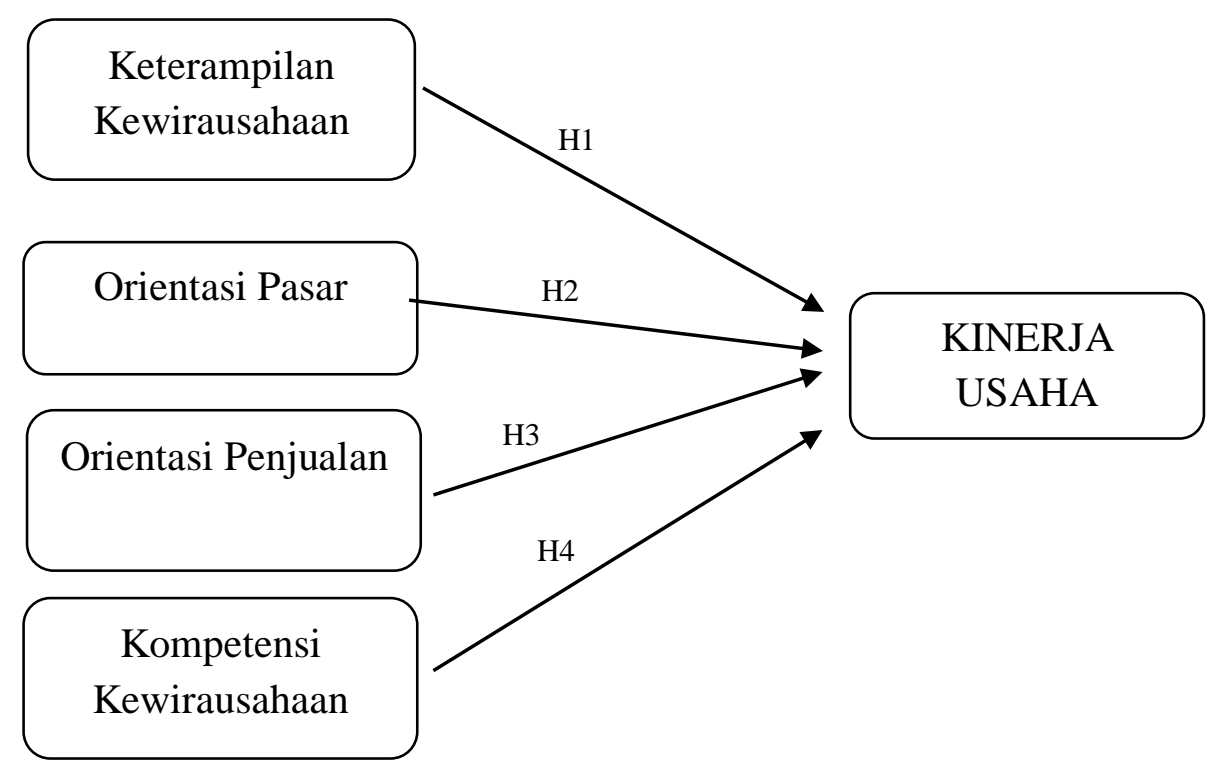

Gambar 1. Model Penelitian

Hipotesis dari model yang dibangun diatas adalah sebagai berikut :

H1: Keterampilan Kewirausahaan berpengaruh terhadap Kinerja UMKM bidang kuliner di Tanjung Duren, Jakarta Barat pada masa pandemi Covid-19.

H2: Orientasi Pasar berpengaruh terhadap Kinerja UMKM bidang kuliner di Tanjung Duren, Jakarta Barat pada masa pandemi Covid-19.

H3: Orientasi Penjualan berpengaruh terhadap Kinerja UMKM bidang kuliner di Tanjung Duren, Jakarta Barat pada masa pandemi Covid-19.

H4: Kompetensi Kewirausahaan berpengaruh terhadap Kinerja UMKM bidang kuliner di Tanjung Duren, Jakarta Barat pada masa pandemi Covid-19.

\section{METODOLOGI}

Desain penelitian akan berisikan gambaran rencana pelaksanaan penelitian, mulai dari awal mula adanya permasalahan sampai dengan rencana akan kegiatan akhir dari suatu penelitian (Aritonang, 1998). Dalam penelitian ini, peneliti menggunakan metode penelitian kausal. Penelitian kausal merupakan penelitian yang dilakukan untuk mencari hubungan antara satu variabel dengan variabel lainnya. Penelitian ini juga memiliki tingkat yang tertinggi apabila dibandingkan dengan penelitian lain. Dengan menggunakan penelitian ini, dapat ditemukan dibeberapa teori yang memberikan penjelasan, perkiraan dan kontrol dari suatu masalah. Hubungan kausal ini merupakan hubungan sebab akibat, salah satu variabel eksogen mempengaruhi variabel endogen. Pada penelitian ini, populasi yang digunakan untuk membuat 
kesimpulan yang lebih luas adalah pemilik UMKM bidang kuliner makanan, dengan sampel yaitu pemilik UMKM bidang kuliner di Tanjung Duren, Jakarta Barat.

Teknik pengambilan sampel yang digunakan dalam penelitian ini adalah teknik nonprobability sampling. Teknik ini merupakan teknik yang tidak memberi peluang atau kesempatan yang sama bagi setiap unit atau individu dari populasi untuk dipilih menjadi sampel. Data yang digunakan dalam penelitian ini adalah data primer, yaitu data yang digunakan langsung dari responden yang terkait dan data yang didapatkan merupakan hasil dari persebaran kuesioner secara online.

Pengukuran tanggapan responden dalam penelitian ini diukur dengan menggunakan skala Likert. Pengukuran skala Likert mengharuskan responden untuk mengisi atau menentukan ketidaksetujuan atau persetujuan mereka terhadap masing - masing pernyataan atau pernyataan dalam kuesioner yang diberikan. Seluruh variabel dalam penelitian ini menggunakan skala Likert 1 sampai 5 dimana 1 = sangat tidak setuju, $2=$ tidak setuju, $3=$ netral, $4=$ setuju, dan 5 = sangat setuju.

\section{HASIL ANALISIS DATA}

Tingkat validitas data dapat dilihat dari nilai validitas konvergen dan validitas diskriminan. Validitas konvergen dinyatakan melalui nilai loading factor pada variabel laten dengan indikator - indikatornya. Indikator dapat dikatakan valid dengan validitas konvergen yang memiliki nilai loading factor lebih besar dari 0,7, namun untuk penelitian tahap awal maka nilai 0,5 sampai 0,6 masih dianggap cukup, dan dapat ditunjukkan oleh nilai Average Variance Extracted (AVE) yang diperoleh bernilai lebih besar dari 0,5.

Nilai AVE dalam penelitian ini adalah untuk Keterampilan Kewirausahaan sebesar 0,657, untuk Orientasi Pasar sebesar 0,631, untuk Orientasi Penjualan sebesar 0,636, untuk Kompetensi Kewirausahaan sebesar 0,709 dan untuk Kinerja Usaha sebesar 0,687. Nilai loading factor dalam penelitian in mempunyai nilai diatas 0,6. Sehingga dapat dikatakan bahwa semua indikator yang digunakan dalam penelitian ini memenuhi syarat.

Tingkat reliabilitas dapat dilihat dari cronbach's alpha dan composite reliability. Suatu data dapat dinyatakan reliable jika hasil cronbach's alpha lebih besar dari 0,6. Nilai composite reliability untuk setiap pernyataan dinyatakan reliabel dan dapat digunakan untuk mengukur suatu variabel jika lebih besar dari 0,7 meskipun nilai 0,6 masih dapat diterima.

Berikut merupakan hasil dari cronbach's alpha dan composite reliability. Cronbach's alpha Keterampilan Kewirausahaan mempunyai nilai 0,824, Orientasi Pasar mempunyai nilai 0,803, Orientasi Penjualan mempunyai nilai 0,808, Keterampilan Kewirausahaan mempunyai nilai 0,862, dan Kinerja Usaha mempunyai nilai 0,886 dan composite reliability Keterampilan Kewirausahaan mempunyai nilai 0,884, Orientasi Pasar mempunyai nilai 0,872, Orientasi Penjualan mempunyai nilai 0,874, Keterampilan Kewirausahaan mempunyai nilai 0,907, dan Kinerja Usaha mempunyai nilai 0,916.

Hasil analisis koefisien determinasi $\left(\mathrm{R}^{2}\right)$ dalam penelitian ini digunakan untuk mengetahui besar pengaruh variabel eksogen terhadap variabel endogen. Apabila nilai $\mathrm{R}$-quare diatas 0,75 maka mempunyai pengaruh yang kuat, sedangkan 0,5 - 0,74 mempunyai pengaruh yang sedang, dan 0,25 - 0,49 mempunyai pengaruh yang lemah. Besarnya pengaruh X1, X2, 
X3, X4 terhadap Y pada penelitian ini adalah sebesar 77,8\%. Sedangkan sisanya $22,2 \%$ dipengaruhi oleh variabel eksogen lainnya.

$\mathrm{Q}^{2}$ merupakan tahap penelitian predictive relevance dari inner model. Jika nilai $\mathrm{Q}^{2}$ lebih besar dari nol maka model memiliki nilai predictive relevance yag baik. Pada penelitian ini nilai $\mathrm{Q}^{2}$ yaitu sebesar 0,513 berarti model ini memiliki predictive relevance.

Hasil dari path coefficient yang ditunjukan pada penelitian ini yaitu Keterampilan Kewirausahaan (+0,273), Orientasi Pasar $(+0,068)$, Orientasi Penjualan $(+0,342)$, dan Kompetensi Kewirausahaan $(+0,285)$.

Pengujian Goodness of Fit $(\mathrm{GoF})$ dilakukan untuk menguji tingkat kecocokan model dalam penelitian ini, nilai GoF dapat dihitung dengan cara manual yaitu dengan memasukkan nilai AVE dan nilai koefisien determinasi $\left(\mathrm{R}^{2}\right)$. Berikut ini merupakan perhitungan nilai GoF

$$
\begin{gathered}
\text { GoF }=\sqrt{\frac{A V E}{\underline{A V}} \times \underline{R^{2}}} \\
\text { GoF }=\sqrt{0,664 \times 0,778}=0,718
\end{gathered}
$$

Nilai GoF sebesar 0,718 memiliki tingkat kesesuaian model yang tergolong besar.

Hasil pengujian hipotesis digunakan untuk melihat pengaruh antara variabel dalam penelitian ini dengan melihat hasil dari metode bootstrapping pada bagian T-Statistics dan PValues. Nilai t-statistics dan p-values pada taraf signifikansi sebesar 95\% adalah lebih dari 1,96 dan kurang dari 0,05 sehingga hipotesis dapat diterima.

Berdasarkan hasil pengujian Keterampilan Kewirausahaan terhadap Kinerja Usaha, dapat dikatakan bahwa Keterampilan Kewirausahaan memiliki pengaruh terhadap Kinerja Usaha. Hal ini dapat dilihat melalui nilai T-statistics yaitu sebesar 2,282 dan P-Values yaitu sebesar 0,023. Berdasarkan hasil pengujian Orientasi Pasar terhadap Kinerja Usaha, dapat dikatakan bahwa Orientasi Pasar tidak memiliki pengaruh terhadap Kinerja Usaha. Hal ini dapat dilihat melalui nilai T-statistics yaitu sebesar 0,363 dan P-Values yaitu sebesar 0,717. Berdasarkan hasil pengujian Orientasi Penjualan terhadap Kinerja Usaha, dapat dikatakan bahwa Orientasi Penjualan memiliki pengaruh terhadap Kinerja Usaha. Hal ini dapat dilihat melalui nilai Tstatistics yaitu sebesar 2,388 dan P-Values yaitu sebesar 0,017. Berdasarkan hasil pengujian Kompetensi Kewirausahaan terhadap Kinerja Usaha, dapat dikatakan bahwa Kompetensi Kewirausahaan memiliki pengaruh terhadap Kinerja Usaha. Hal ini dapat dilihat melalui nilai T-statistics yaitu sebesar 2,435 dan P-Values yaitu sebesar 0,015.Berdasarkan penjelasan diatas, dapat dikatakan bahwa hanya Orientasi Pasar yang tidak memiliki pengaruh terhadap Kinerja Usaha, tetapi Keterampilan Kewirausahaan, Orientasi Pasar, Orientasi Penjualan, dan Kompetensi Kewirausahaan. Memiliki pengaruh terhadap Kinerja Usaha.

\section{DISKUSI}

Hasil pengujian hipotesis menyatakan bahwa Keterampilan Kewiraushaan memiliki pengaruh terhadap Kinerja Usaha. Pengujian hipotesis ini sesuai dengan penelitian sebelumnya yang mempengaruhi kinerja usaha. Keterampilan kewirausahaan merupakan sumber daya perusahaan, sehingga mempengaruhi kinerja usaha secara langsung dan tidak langsung (Abdullah et al, 2019). Dalam penelitian sebelumnya mengatakan keterampilan mengacu pada kemungkinan belajar dan mengadopsi karakteristik pada pemilik usaha (Pyysiäinen et al, 2006). Seorang pemilik UMKM sangat memerlukan berbagai keterampilan untuk 
mengembangkan, mengelola, dan menghasilkan kinerja perusahaan yang baik karena keterampilan kewirausahaan merupakan kunci penting bagi sebuah usaha (Campbell et al, 2012).

Maka keterampilan kewirausahaan ini penting karena merupakan suatu kegiatan atau pengetahuan yang membantu menumbuhkan kepribadian dan karakter seorang pemilik UMKM menjadi lebih berkompeten dan bertanggung jawab dalam menjalankan usahanya. Seorang pemilik UMKM akan lebih kreatif dan memiliki keterampilan dalam memecahkan masalah yang sedang dihadapi yang berguna dalam mengelola sebuah usaha.

Kemudian pengujian hipotesis pada Orientasi Pasar tidak memiliki pengaruh terhadap Kinerja Usaha. Hasil tersebut bertentangan dengan penelitian sebelumnya yang menyatakan bahwa orientasi pasar memiliki hubungan terhadap kinerja usaha. Orientasi pasar merupakan bagian dari kompetensi kewirausahaan tambahan yang memfasilitasi kinerja usaha mikro. Orientasi pasar merupakan peran penting dan berpengaruh pada kinerja usaha yang dimediasi oleh kompetensi kewirausahaan. Orientasi pasar dikatakan dapat meningkatkan kinerja dengan menciptakan nilai bagi pelanggan dengan keunggulan kompetitif (Abdullah et al, 2019). Namun pada penelitian lain menyatakan bahwa tidak adanya hubungan yang signifikan antara orientasi pasar dan kinerja usaha (Au \& Tse, 1995). Orientasi pasar bukan merupakan predictor kinerja UMKM (Demirbag, K.S.C., Tatoglu, \& Zaim, 2006).

Maka dari itu, agar orientasi pasar dapat meningkat sebagai sarana bagi sebuah perusahaan ada beberapa hal yang harus diperhatikan bagi pemilik UMKM. Seorang pemilik UMKM tidak perlu menawarkan produk kepada pelanggan jika produk tersebut tidak tepat bagi pelanggan karena pemilik UMKM harus mengetahui target pelanggan yang akan dituju sebelum menjual produk tersebut. Selain itu, pemilik usaha juga harus lebih memperhatikan perubahan kebutuhan pasar dan pemahaman kebutuhan pelanggan, dengan memberikan informasi jelas tentang produk dan menjual jenis produk tergantung pada situasi yang ada di pasar akan membantu meningkatkan penjualan produk tersebut. Pemilik akan dengan mudah menemukan pelanggan yang sesuai sehingga dapat meningkatkan kinerja usaha jika target pelanggannya tepat.

Kemudian pengujian hipotesis Orientasi Penjualan memiliki pengaruh terhadap Kinerja Usaha. Hasil penelitian ini bertentangan dengan penelitian sebelumnya yang menyatakan bahwa orientasi penjualan tidak berpengaruh terhadap kinerja usaha. Hal ini dibuktikan bahwa terdapat pengaruh rendah orientasi penjualan dengan kinerja usaha. Penelitian ini juga mengatakan bahwa pendekatan yang berorientasi penjualan tidak selalu penting bagi suatu usaha, tetapi dibutuhkan dalam kinerja tenaga penjualan (Abdullah et al, 2019). Namun, pada penelitian lain menyatakan bahwa orientasi penjualan mempunyai pengaruh terhadap kinerja usaha (Trent et al, 2009).

Pemilik UMKM yang memprioritaskan dan berfokus pada penjualan, akan mempunyai keunggulan kompetitif yang akan mempengaruhi kinerja usaha. Dengan berfokus orientasi penjualan akan mempunyai pengaruh pada kinerja usaha, dimana biasanya tenaga penjual yang memiliki keterampilan menjual yang rendah seperti mengidentifikasi kebutuhan, mencocokkan produk dengan kebutuhan.

Kemudian pengujian hipotesis Kompetensi Kewirausahaan memiliki pengaruh terhadap Kinerja Usaha. Hasil dari penelitian ini sesuai dengan penelitian sebelumnya yang menunjukkan kompetensi kewirausahaan sebagai mediasi dari keterampilan kewirausahaan, 
orientasi pasar dan orientasi penjualan terhadap kinerja perusahaan. Dan dari kompetensi kewirausahaan itu sendiri memiliki pengaruh terhadap kinerja usaha yang cukup tinggi dan memiliki kemampuan yang penting dalam menentukan kinerja perusahaan (Abdullah et al , 2019). Seorang pemilik UMKM membutuhkan kompetensi kewirausahaan karena berhubungan dengan karakteristik dalam diri pemilik UMKM yang melibatkan sikap dan perilaku. Dengan ini dapat membantu usaha mencapai keunggulan kompetitif karena seorang pemilik dengan cermat menganalisa dan mengidentifikasi produk yang ingin ditawarkan ke pelanggan serta mengembangkan hubungan kepercayaan dengan pelanggan yang membuat pelanggan ingin datang kembali untuk membeli.

\section{PENUTUP}

Dari penelitian ini, dapat diketahui bahwa keterampilan kewirausahaan, orientasi penjualan,, dan kompetensi kewirausahaan memiliki pengaruh positif dan signifikan terhadap kinerja usaha dan orientasi pasar memiliki pengaruh positif dan tidak signifikan terhadap kinerja usaha. Terkait dengan penelitian yang telah dilakukan, ada beberapa saran yang diharapkan dapatt bermanfaat, berikut saran - saran dari peneliti : 1) Pemilik UMKM bidang kuliner perlu mengembangkan kepribadian dan karakter dalam diri sehingga menjadi lebih kreatif, berkompeten dan bertanggung jawab untuk meningkatkan usahanya. 2) Pemilik UMKM bidang kulier perlu melakukan pemasaran dengan meperhatikan perubahan kebutuhan nyata pasar, menargetkan pelanggan sesuai dengan produk penjualan serta memberikan informasi produk dengan menarik dan lengkap untuk menarik minat pelanggan. 3) Peneliti selanjutnya disarankan untuk menambah variabel - variabel yang lain selain yang sudah diteliti dalam penelitian ini. 4) Peneliti selanjutnya diharapkan untuk memperluas jangkauan dalam pengambilan sampel dan jumlah sampel yang digunakan agar memperoleh hasil yang lebih baik dan akurat.

\section{DAFTAR PUSTAKA}

Abdullah, A. M., Syed, A. F., \& Rajennd, M. (2019). Entrepreneurial knowledge, skill, competencies and performance : A study of micro-enterprises in Kelantan, Malaysia. Asia Pasific Journal of Innovation and Entrepreneurship, 13(1), 29-48.

Aritonang, L. R. (1998). Penelitian Pemasaran. Universitas Tarumanagara: UPT Penerbitan.

Atuahene-Gima, K., \& Ko, A. (2001). An empirical investigation of the effect of market orientation and entrepreneurship orientation alignment on product innovation. Organization Science, 12(1), 54-74.

$\mathrm{Au}, \mathrm{A} ., \quad \&$ Tse, A. (1995). The effects of market orientation on company performance in the service sector : a comparative study in Hongkong and New Zealand. Journal of International Consumer Marketing, 8(2), 77-87.

Barney, J. (1991). Firm resources and sustained competitive advantage. Journal of Management, 17(1), 99-120.

Barney, J. B. (1986). Strategic factor markets: Expectations, luck, and business strategy. . Management Science, , 32(10), 1231-1242.

Boles, J., Howard, W., \& Donofrio, H. (2001). An investigation into the inter-relationship of work family conflict, family work conflict and work satisfaction. . Journal of Managerial Issues, Vol. 13(3), 376-390. 
BPS. (2018). Statistik Penyediaan Makanan dan Minuman (Food and Beverage Service Activities Statistics).

Burhan, F. (2020). Bisnis Anjlok akibat Pandemi Corona UMKM Bisa Ubah Strategi Usaha. Jakarta.

Campbell, B., Ganco, M., Franco, A., \& Agarwal, R. (2012). Who leaves, where and why worry? Employee mobility, entrepreneurship and effects on source firm performance. Strategic Management Journal, 33(1), 65-87.

Demirbag, M., K.S.C., L., Tatoglu, K., \& Zaim, S. (2006). TQM and Market Orientations impact on SME's performance. Industrial Management and Data System, 106(8), 12061228.

Dicksen, P. R. (1996). The static and dynamic mechanics of competitive theory. Journal of Marketing, 60, 102-106.

Endi, S., Surachman, A., \& Djumilah, H. (2013). Entrepreneur Characteristics and Competency as Determinants of Business Performance in SMEs. IOSR . Journal of Business and Management, 7(3), 31-38.

Gerli, F., Gubitta, P., \& Tognazzo, A. (2011). Entrepreneurial competencies and firm performance: an empirical study. "Entrepreneurial competencies and firm performance: an empirical study. VIII International Workshop on Human Resource Management Conference Proceedings, Seville.

Grant, R. (1991). The resource-based theory of competitive advantage: implications for strategy formulation. California Management Review, 33(3), 114-135.

Jaramillo, F., Ladik, D., Marshall, G., \& Mulki, J. (2007). A meta- analysis of the relationship between sales orientation customer orientation (SOCO) and salesperson job performance. Journal of Business and Industrial Marketing, 22(5), 302-31.

Kohli, A., \& Jawarski, B. (1990). Market orientation the construct, research propositions and managerial implications. . The Journal of Marketing, 54(2), 1-18.

Linan, F., \& Chen, Y. (n.d.). Development and cross cultural application of a specific instrument to measure entrepreneurial intentions. Entrepreneurship Theory and Practice, 4(3), 257-272.

Mitchelmore, S., \& Rowley, J. (2010). Entrepreneurial competencies: a literature review anddevelopment agenda. International Journal of Entrepreneurial Behavior and Research, 16(2), 92-111.

Morgan, N., Vorhies, D., \& Mason, C. (2009). Market Orientation, marketing capabilities and firm performance. . Strategic Management Journal, 30(8), 909-920.

Muslimu, K., \& Alhassan, M. (2020). Effect of entrepreneurial skills on small and medium scale enterprises (SMEs) performance: a study of registered businesses operating in sabon gari market kano. . Internasional Journal of Advanced Academic Research (Social and Management Sciences), 6(10).

Narver, J., \& Slater, S. (1990). The effect of a market orientation on business profitability. The Journal of Marketing, Vol. 54 No. 4, pp. 20-35.

Phelan, C., \& Sharpley, R. (2012). Exploring entrepreneurial skills and competencies in farm tourism. Local Economy: The Journal of the Local Economy Policy Unit, 27(2), 103-118.

Pyysiäinen, J., Anderson, A., McElwee, G., \& Vesala, K. (2006). Developing the entrepreneurial skills of farmers: some myths explored. International Journal of Entrepreneurial Behavior and Research, 12(1), 21-39.

Rizan, J., \& Utama, L. (2020). Pengaruh Keterampilan Kewirausahaan, Orientasi Pasar dan Orientasi Penjualan terhadap Kinerja Usaha UMKM. Jurnal Manajerial dan Kewirausahaan, 2(4), 961-968.

Rumelt, R., Schendel, D., \& Teece, D. (1994). Fundamental Issues in Strategy. Cambridge, MA: Harvard University Press. 
Sugiyono. (2015). Metode Penelitian Kombinasi (Mix Methods). Bandung: Alfabeta.

Tehseen, S., \& Ramayah. (2015). Entrepreneurial competencies and SMEs business success:

The contingent role of external integration. Mediterranean Journal of Social Sciences, 6 (1), 50 .

Trent, W., Christopher, R., Plouffe, B., \& Gregoire. (2009). SOCO's impact on Individual Sales Performance : The integration of selling skills as a missing link. . Industrial Marketing Management, 32-44.

Utama, L., \& Nadi, J. (2017). Pengaruh Kreativitas terhadap Kinerja Usaha dengan orientasi kewirausahaan sebagai mediasi pada wirausaha di ITC Cempaka Mas. Conference on Managerial and Behavorial Studies, 80-88.

Wetzels, M. K., \& Lemmink, J. (2000). Antecedents and conse-quences of services. in Hand business to business services. In Hand book of services marketing and management. 343356.

$\mathrm{Wu}, \mathrm{W}$. (2009). A competency based model for the sucess of an entrepreneurial start up. WSEAS Transactions of business and economics. 6(6), 279-291. 